\title{
CONTAMINATION OF WHEAT GRAINS WITH SPECIES OF GENERA FUSARIUM IN DIFFERENT LOCALITIES OF SLOVAKIA IN 2006-2008
}

\author{
VALÉRIA ŠUDYOVÁ, SVETLANA ŠLIKOVÁ
}

Plant Production Research Center Piešt'any

ŠUDYOVÁ, V. - ŠLIKOVÁ, S.: Contamination of wheat grains with species of genera Fusarium in different localities of Slovakia in 2006-2008. Agriculture (Pol'nohospodárstvo), vol. 57, 2011, no. 3, pp. 110-117.

\begin{abstract}
The frequency and relative density of occurrence of Fusarium spp. was evaluated on 112 wheat grain samples from different agro-ecological localities in Slovakia. The samples were collected in 2006, 2007 and 2008 from the same farmers and from the same localities every year immediately after harvest. In 2006 , contamination was $95.2 \%$, in 2007 it was $64.3 \%$, and $71.4 \%$ in 2008 . The highest average frequency of occurrence was found in Fusarium graminearum in $2006-65 \%$. The prevalence of Fusarium poae was ascertained in 2007 and 2008. The highest frequency of Fusarium spp. occurrence was revealed in locality Turčiansky Ďur in $2008-53.9 \%$. The highest identified amount of Fusarium species (12) was from the area of Turčiansky Ďur in 2007. Fusarium graminearum, Fusari-
\end{abstract}

Key words: Fusarium, frequency of occurrence, year, locality

Several Fungi of Fusarium genus, as important plant pathogens, attack wheat during growth and storage, if the grain is not dried sufficiently (Stenglein 2009). The intensity of disease incidence is heavily dependent on weather conditions during vegetation, forecrop and tillage method. In the stage of flowering and grain development wheat is most susceptible to Fusarium Head Blight (FHB) and the key role is played by weather conditions. Wheat grains are colonized by several Fusarium species and form a complex with other species of microscopic fungi of Alternaria, Epicoccum, Botrytis or Aspergillus genera (Tančinová et al. 2009). In Europe, the prevaling species are F. culmorum (W. G. Smith) Saccard, F. graminearum Schwabe, (Gibberella zeae Schwein (Petch), F. avenaceum (Fries) Saccardo (Gibberella avenaceae) and F. poae (Peck) um sporotrichioides, Fusarium poae and Fusarium oxysporum were the most frequent in 2006, while Fusarium poae, Fusarium sporotrichioides, Fusarium graminearum and Fusarium semitectum dominated in 2007. Fusarium poae dominated in 2008, then followed Fusarium sporotrichioides, Fusarium graminearum, Fusarium oxysporum and Fusarium avenaceum. Other identified species, such as Fusarium equiseti, Fusarium tricinctum and Microdochium nivale, were in population structure in a relatively low density. Grains contaminated with Fusarium spp. are unsuitable for both human and animal consumption because of the adverse health effects of fusariotoxins..

Wollenweber (Nicholson et al. 1997, cit. Vogelgsang et al. 2008; Zemánková \& Lebeda 2001; Bottalico \& Perrone 2002). Species composition is different not only in crops, but it is also related to climatic conditions of the locality. The prevailing species in colder areas are F. culmorum, $F$. avenaceum, $F$. poae, in warmer areas dominate $F$. graminearum, F. solani (Martius) Appel \& Woll. emend. Snyder \& Hansen (Nectria haematococca), F. equiseti (Corda) Sacc., F. oxysporum Schltdl. Emend Snyder \& Hansen. The frequency of occurrence and the spectrum of species are not stable, they vary depending on the year, varietal composition and development of weather in the time of infection and vary also in different countries. In the period from 1976 to 1981 the most frequent species on wheat was F. avenaceum in Estonia. Results of the analysis of the

Ing. Valéria Šudyová, CSc., Ing. Svetlana Šliková, PhD., Plant Production Research Center Piešt’any, 92168 Piešt’any, Bratislavská cesta 122, Slovak Republic.E-mail: sudyova@vurv.sk, slikova@vurv.sk 
years 2002-2003 revealed a change in species composition, the most frequently occurring species was $F$. semitectum Berkely \& Ravenel, followed by F. poae, F. culmorum and $F$. avenaceum (Löiveke et al. 2003). Changes in the structure of species were observed in wheat samples in the Netherlands between 1980 and 1990, prevailing species was F. culmorum. Analyses from the years 2000 and 2001 confirmed the prevalence of $F$. graminearum before $F$. culmorum and $M$. nivale (F. nivale, Monographella nivalis (Schaffnit) E. Müll.) (Waalwijk et al. 2003). In Germany in 2003, occurred mainly F. graminearum (52\%), F. poae, F. avenaceum, F. equiseti, F. tricinctum (Corda) Sacc. (Gibberella pulicaris (Fr.) Sacc.). Since 1990, the main species in Poland was $F$. poae (64\%), followed by F. tricinctum $(15 \%), F$. avenaceum (8\%), F. culmorum (6\%) and $F$. graminearum (4\%) (Goliński et al. 1997). Overall, the level of FHB before 2000 was low in the south of Poland, in 2005 and 2006 five times higher frequency of $F$. graminearum and reduced frequency of $F$. culmorum were recorded (Tomczak et al. 2002; Stepień et al. 2008). In the years $2003-2005,92.1 \%$ of wheat and barley samples collected from different localities in Lithuania were contaminated by fungi of Fusarium (Mačkinaitë et al. 2006). The spectrum of species varied depending on climatic conditions and type of cereals. Contamination of barley grains was higher than contamination of wheat grains and reached $97.1 \%$. Changes of species spectrum were also found between the years, in 2003 prevalent species isolated from the surface of wheat grains were $F$. moniliforme J. Sheld (Gibberella moniliformis Wineland), F. avenaceum, $F$. graminearum and $F$. oxysporum, in $2004 F$. poae, $F$. sporotrichioides Scherb. and F. equiseti, in 2005 F. graminearum was dominating, while $F$. equiseti has not been isolated. According to the study of Hýsek et al. (1999) F. culmorum was the dominant species in the Czech Republic. Weather changes start also to affect the spectrum of Fusarium species, F. graminearum began to prevail (Ostrý et al. 2004) and recent studies show the increasing representation of F. poae. Harmfulness of Fusarium fungi lies not only in deterioration of technological, nutritional and hygienic quality of production. Conditions suitable for the development of Fusarium spp. are also suitable for the production of mycotoxins in grain (Doohan et al. 2003; Xu 2003). Limitation of Fusarium spp. incidence and hence also mycotoxins incidence in grain can be partially elimi- nated by compliance with agro-technical measures, timely application of fungicides yet at a stage when the disease is on the leaves as well as by proper storage of grain. Monitoring of Fusarium spp. occurrence and prediction of disease incidence by phytopathological and molecular analyses should be important factors. Wheat products are an indispensable part of human and animal nutrition and production of healthy food must be an essential part of a healthy environment.

The goal of the study was to evaluate contamination of wheat grain from different agro-ecological localities of Slovakia in the years 2006 to 2008 and find prevalence of Fusarium spp. in the studied localities and years.

\section{MATERIAL AND METHODS}

\section{Grain samples}

Grain samples of commercial cultivars of winter wheat, a total of 112, came from 10 localities of Slovakia situated in different agro-ecological conditions. Samples were taken directly from the producers immediately after harvest in $1 \mathrm{~kg}$ quantities from the land, where the standard procedures were used, including application of fungicides. In the years studied wheat grain samples were always supplied by the same producer, from the same locality but from different fields in accordance with crop rotation. In the studied years the number of samples varied: in 2006, 21 samples were processed, in 2007, 42 samples and in 2008, 49 samples.

\section{Isolation and identification of fungi of Fusarium ge-} nus

Grains of wheat samples were surface-sterilized in $1 \% \mathrm{NaOCl}$ solution for 2 minutes. They were subsequently rinsed three times in re-distilled water and cultured in Petri dishes $(\varnothing 8 \mathrm{~cm})$ on potato-dextrose agar (PDA) in a biological thermostat at $23^{\circ} \mathrm{C}$ for $5-7$ days. For each sample, 100 randomly selected grains were tested. From the developed colonies mycelium was reisolated and re-cultured in Petri dishes on synthetic nutrient medium (SNA) under UV-light, photoperiod 12 hours by day $/ 12$ hours by night, temperature of $24^{\circ} \mathrm{C}$. To determine the species the classical identification based on microscopic characteristics according to the laboratory manuals Gerlach and Nirenberg (1982) and 
Leslie and Summerell (2006) were used.

The frequency of occurrence and relative density of Fusarium spp.

Studied indicators were calculated according to formulas by Gonzáles et al. (1996):

Frequency of occurrence $(\mathrm{Fr} \%)=(\mathrm{ns} / \mathrm{N}) \times 100$ ns $=$ number of samples in which genus or species were detected,

$\mathrm{N}=$ total number of samples.

Relative density $(\mathrm{RD} \%)=(\mathrm{ni} / \mathrm{Ni}) \times 100$

$\mathrm{ni}=$ number of isolates of genus or species,

$\mathrm{Ni}=$ total number of detected isolates.

Relative density in percentage (arcsin transformation) were statistically evaluated by analysis of variance (ANOVA) using SPSS software.

\section{RESULTS AND DISCUSSION}

The determination of Fusarium spp. was made from 112 analyzed samples of wheat grain. In the period from 2006 to 2008 , contaminated samples formed
$73.2 \%$. The highest contamination was found in 2006 (95.2\%), the lowest in 2007 (64.3\%). Totally 12 Fusarium species have been identified: $F$. graminearum, $F$. poae, F. sporotrichioides, F. culmorum, F. tricinctum, F. semitectum, F. avenaceum, $F$. sambucinum, F. oxysporum, F. equiseti, F. compactum and M. nivale. Due to contamination by other microscopic fungi not all the species of Fusarium have been identified in some samples, in different years their frequency was from 0.3 to $1.3 \%$. In 2006, on average, the highest frequency of occurrence was recorded in $F$. graminearum, followed by F. sporotrichioides and F. poae (Fig. 1). The same order of the species was in the relative density of occurrence (Table 1). Regarding the localities, the highest average frequency of occurrence was in Sládkovičovo in 2006 (52.8\%, Fig. 2), seven Fusarium species have been identified. The $100 \%$ frequency was in $F$. graminearum, F. poae, F. sporotrichioides, F. semitectum, F. oxysporum and F. compactum, the species producing trichothecenes of the groups A and B. The location Vel'ký Meder follows with the average occurrence frequency of $48.8 \%$, Spišské Vlachy $(45.8 \%)$ and $\mathrm{Ab}$ rahám $(33.3 \%)$. The area in which Vel'ký Meder is located is the area with higher temperatures and in 2006 there was also relatively high rainfall (Table 4). These

$\mathrm{T}$ a b 1 e 1

The relative density [\%] of Fusarium species in 2006 from wheat grain surface in Slovakia

\begin{tabular}{|c|c|c|c|c|c|c|c|c|c|c|c|c|c|}
\hline \multirow{2}{*}{ Locality } & \multicolumn{12}{|c|}{ Fusarium species } & \multirow{2}{*}{$\begin{array}{l}\text { Locality } \\
\text { RD [\%] }\end{array}$} \\
\hline & gram & poae & sporo & culm & tric & semit & aven & samb & oxys & equi & com & $\mathrm{Mn}$ & \\
\hline Abrahám & 14.8 & 0.0 & 8.8 & 0.0 & 0.0 & 1.8 & 0.0 & 0.0 & 8.8 & 0.0 & 5.3 & 0.0 & 3.2 \\
\hline Vel'ký Meder & 5.3 & 0.0 & 5.3 & 4.0 & 2.7 & 2.7 & 0.0 & 0.0 & 2.7 & 0.0 & 1.3 & 0.0 & 2.0 \\
\hline Želiezovce & 5.3 & 2.6 & 2.6 & 0.0 & 0.0 & 2.6 & 0.0 & 0.0 & 0.0 & 0.0 & 4.0 & 0.0 & 1.4 \\
\hline Sládkovičovo & 4.6 & 16.3 & 9.3 & 0.0 & 4.6 & 2.3 & 0.0 & 0.0 & 2.3 & 0.0 & 2.3 & 0.0 & 3.4 \\
\hline V. Ripňany & 5.6 & 0.0 & 5.6 & 0.0 & 0.0 & 0.0 & 0.0 & 0.0 & 1.9 & 0.0 & 0.0 & 0.0 & 1.0 \\
\hline Turčiansky Ďur & 7.6 & 5.5 & 2.5 & 0.0 & 0.0 & 0.0 & 0.0 & 0.0 & 0.0 & 5.5 & 0.0 & 7.6 & 2.3 \\
\hline Malý Šariš & 0.0 & 9.3 & 2.6 & 0.0 & 0.0 & 0.0 & 0.0 & 0.0 & 2.6 & 0.0 & 0.0 & 1.3 & 1.3 \\
\hline Spišské Vlachy & 9.0 & 5.4 & 5.4 & 0.0 & 3.6 & 0.0 & 7.3 & 0.0 & 5.4 & 5.4 & 0.0 & 0.0 & 3.4 \\
\hline Spišská Belá & 7.1 & 7.1 & 2.3 & 0.0 & 0.0 & 0.0 & 7.1 & 0.0 & 0.0 & 4.7 & 0.0 & 7.1 & 2.9 \\
\hline Vranov nad Toplou & 7.2 & 5.4 & 3.6 & 0.0 & 0.0 & 0.0 & 3.6 & 0.0 & 5.4 & 0.0 & 0.0 & 0.0 & 2.1 \\
\hline Average & 6.6 & 5.2 & 4.8 & 0.4 & 1.1 & 0.9 & 1.8 & 0.0 & 2.9 & 1.6 & 1.3 & 1.6 & 2.3 \\
\hline
\end{tabular}

gram $-F$. graminearum; poae $-F$. poae; sporo $-F$. sporotrichioides; culm $-F$. culmorum; tric $-F$. tricinctum; semit $-F$ semitectum; aven $-F$. avenaceum; samb - F. sambucinum; oxys $-F$. oxysporum; equi $-F$. equiseti; com - F. compactum; $\mathrm{Mn}-M$. nivale ${ }^{*}$ not significant differences between the means (ANOVA, Duncan test, $\mathrm{p}=0.05$ ) 


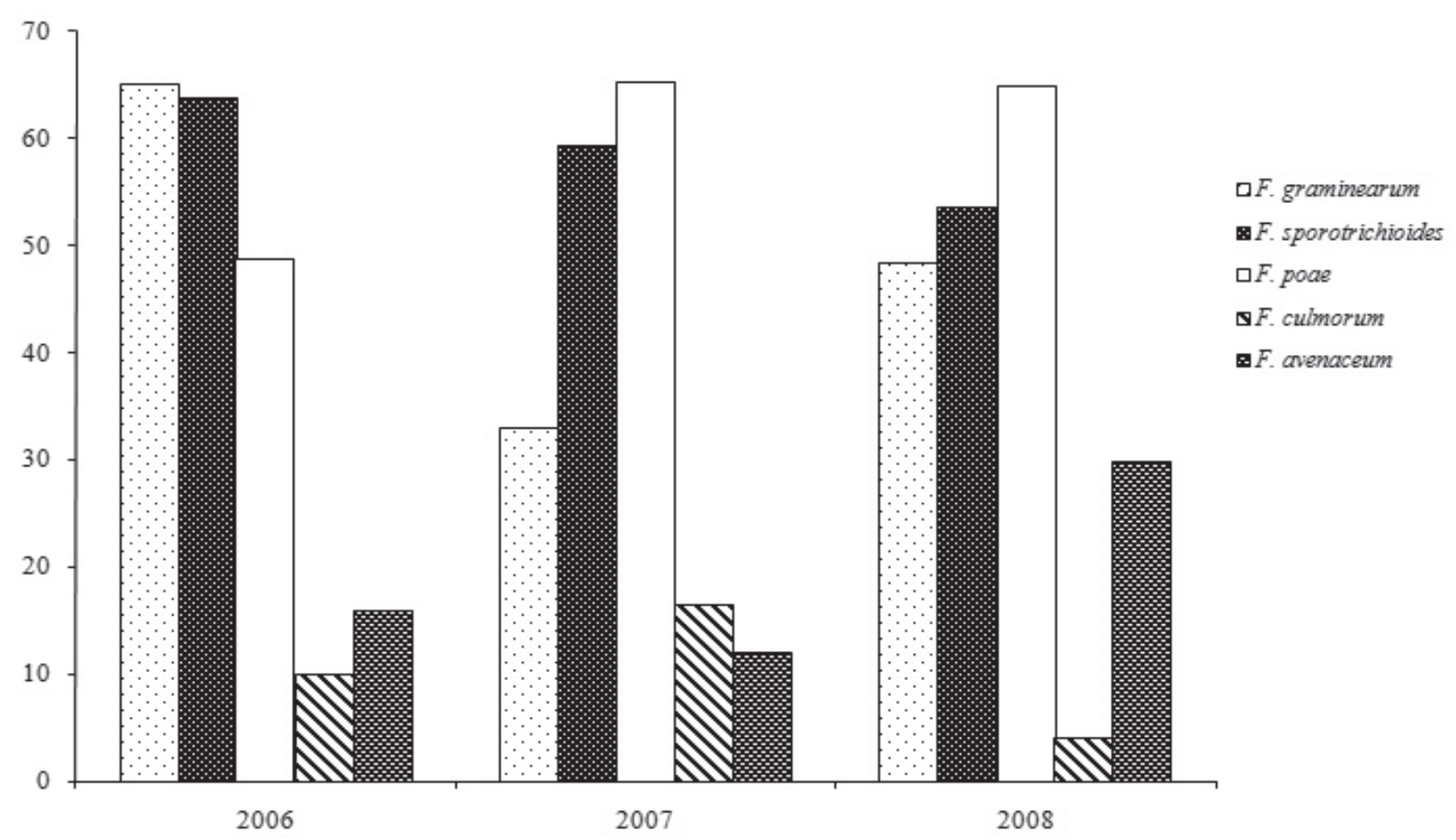

Fig. 1. The average frequency (\%) of occurrence of Fusarium species in 2006-2008 from wheat grain surface re-isolated on SNA medium in Slovakia (without minor species)

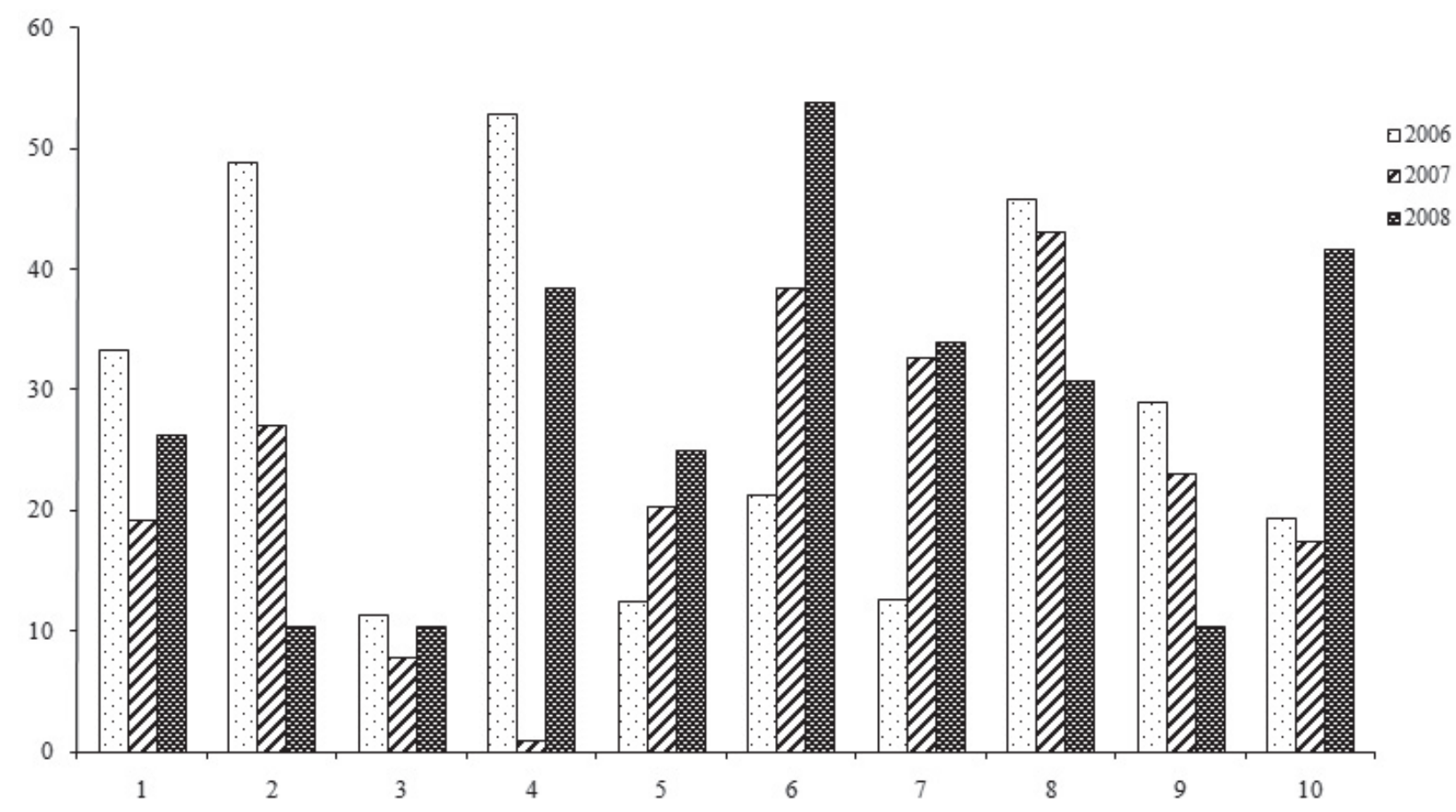

1-Abrahám; 2-Vel'ký Meder; 3-Želiezovce; 4-Sládkovičovo; 5-Vel'ké Ripňany; 6-Turčiansky Ďur; 7-Malý Šariš; 8-Spišské Vlachy; 9-Spišská Belá; 10-Vranov n/Topl’ou

Fig. 2. The frequency (\%) of occurrence of Fusarium spp. in 2006-2008 from wheat grain surface re-isolated on SNA medium in localities of Slovakia 
weather conditions were favourable for the occurrence of thermophilous species such as $F$. graminearum and $F$. semitectum, but also $F$. culmorum, considered to be psychrophilous species, was identified. On the contrary, in the localities Spišské Vlachy, Vranov nad Toplou, Spišská Belá and Turčiansky Dur (localities with a colder climate), F. graminearum in frequency from $37.5 \%$ to $100 \%$ was identified. In these locations

$\mathrm{T}$ a b 1 e 2

The relative density [\%] of Fusarium species in 2007 from wheat grain surface in Slovakia

\begin{tabular}{|c|c|c|c|c|c|c|c|c|c|c|c|c|c|}
\hline \multirow[t]{2}{*}{ Locality } & \multicolumn{12}{|c|}{ Fusarium species } & \multirow{2}{*}{$\begin{array}{l}\text { Locality } \\
\text { RD [\%] }\end{array}$} \\
\hline & gram & poae & sporo & culm & tric & semit & aven & samb & oxys & equi & com & $\mathrm{Mn}$ & \\
\hline Abrahám & 7.5 & 2.5 & 2.5 & 0.0 & 2.5 & 7.5 & 0.0 & 2.5 & 5.0 & 0.0 & 7.5 & 0.0 & $3.1^{\mathrm{abc}}$ \\
\hline Vel'ký Meder & 1.3 & 7.6 & 7.6 & 5.7 & 0.0 & 5.7 & 0.0 & 7.6 & 0.0 & 0.0 & 0.0 & 0.0 & $2.9^{\mathrm{ab}}$ \\
\hline Želiezovce & 0.0 & 16.7 & 3.3 & 0.0 & 0.0 & 0.0 & 0.0 & 0.0 & 3.3 & 0.0 & 0.0 & 0.0 & $1.9^{\mathrm{ab}}$ \\
\hline Sládkovičovo & 0.0 & 2.8 & 0.0 & 0.0 & 0.0 & 0.0 & 0.0 & 0.0 & 0.0 & 0.0 & 0.0 & 0.0 & $0.2^{\mathrm{a}}$ \\
\hline Vel'ké Ripňany & 8.5 & 2.8 & 0.0 & 2.8 & 0.0 & 5.7 & 0.0 & 0.0 & 2.8 & 0.0 & 8.5 & 0.0 & $2.5^{\mathrm{ab}}$ \\
\hline Turčiansky Ďur & 9.0 & 25.4 & 21.8 & 3.6 & 3.6 & 7.2 & 3.6 & 1.8 & 7.2 & 1.8 & 3.6 & 1.8 & $7.5^{\mathrm{cd}}$ \\
\hline Malý Šariš & 13.5 & 43.7 & 15.4 & 0.0 & 6.4 & 5.7 & 4.6 & 0.0 & 3.8 & 1.9 & 0.0 & 3.8 & $8.2^{\mathrm{d}}$ \\
\hline Spišské Vlachy & 19.2 & 28.0 & 15.8 & 5.3 & 5.3 & 8.8 & 7.0 & 0.0 & 1.7 & 3.5 & 1.7 & 3.5 & $8.3^{\mathrm{d}}$ \\
\hline Spišská Belá & 5.3 & 10.5 & 3.5 & 0.0 & 1.7 & 7.0 & 5.3 & 0.0 & 0.0 & 7.0 & 0.0 & 0.0 & $3.3^{\mathrm{bc}}$ \\
\hline Vranov nad Topl'ou & 0.0 & 17.8 & 10.6 & 0.0 & 6.4 & 0.0 & 0.0 & 0.0 & 0.0 & 0.0 & 0.0 & 0.0 & $2.9^{\mathrm{ab}}$ \\
\hline Average & 6.4 & 15.8 & 8.1 & 1.7 & 2.6 & 4.8 & 2.1 & 1.2 & 2.4 & 1.4 & 2.1 & 0.9 & 4.1 \\
\hline
\end{tabular}

gram - F. graminearum; poae - F. poae; sporo - F. sporotrichioides; culm - F. culmorum; tric - F. tricinctum; semit - F semitectum; aven - F. avenaceum; samb - F. sambucinum; oxys - F. oxysporum; equi - F. equiseti; com - F. compactum; Mn - M. nivale; * differences between values designated by the same letter are not significant (ANOVA, Duncan test, $\mathrm{p}=0.05$ )

$\mathrm{T}$ a $\mathrm{b} 1$ e 3

The relative density [\%] of Fusarium species in 2008 from wheat grain surface in Slovakia

\begin{tabular}{|l|r|r|r|r|r|r|r|r|r|r|r|r|r|}
\hline \multirow{2}{*}{ Locality } & \multicolumn{10}{|c|}{ Fusarium species } & Locality \\
& \multicolumn{1}{|c|}{ gram } & poae & sporo & culm & \multicolumn{1}{|c|}{ tric } & semit & aven & samb & oxys & equi & com & Mn & RD [\% $]^{*}$ \\
\hline Abrahám & 14.2 & 42.4 & 29.3 & 0.0 & 0.0 & 2.8 & 2.8 & 0.0 & 3.3 & 2.8 & 0.0 & 1.8 & $8.2^{\text {cd }}$ \\
Vel'ký Meder & 0.0 & 10.0 & 6.6 & 0.0 & 0.0 & 0.0 & 0.0 & 0.0 & 0.0 & 0.0 & 0.0 & 0.0 & $1.3^{\mathrm{a}}$ \\
Želiezovce & 0.0 & 10.0 & 10.0 & 0.0 & 0.0 & 0.0 & 0.0 & 0.0 & 0.0 & 0.0 & 0.0 & 0.0 & $1.6^{\mathrm{a}}$ \\
Sládkovičovo & 2.5 & 2.5 & 2.5 & 0.0 & 0.0 & 2.5 & 2.5 & 5.0 & 7.5 & 0.0 & 5.0 & 2.5 & $2.7^{\text {abc }}$ \\
Vel'ké Ripňany & 20.0 & 6.6 & 13.3 & 0.0 & 0.0 & 10.0 & 3.3 & 3.3 & 20.0 & 0.0 & 10.0 & 13.3 & $8.3^{\text {cd }}$ \\
Turčiansky Ďur & 29.2 & 12.3 & 9.2 & 15.4 & 3.0 & 3.0 & 6.1 & 4.6 & 6.1 & 0.0 & 1.5 & 9.2 & $8.3^{\mathrm{d}}$ \\
Malý Šariš & 5.0 & 6.6 & 6.6 & 1.6 & 0.0 & 3.3 & 3.3 & 0.0 & 3.3 & 0.0 & 0.0 & 3.3 & $2.7^{\text {abc }}$ \\
Spišské Vlachy & 7.7 & 5.8 & 3.8 & 3.8 & 1.9 & 3.8 & 5.8 & 0.0 & 3.8 & 3.8 & 5.8 & 9.6 & $4.6^{\text {bcd }}$ \\
Spišská Belá & 3.1 & 6.2 & 6.2 & 0.0 & 0.0 & 0.0 & 0.0 & 0.0 & 0.0 & 0.0 & 0.0 & 3.1 & $1.5^{\mathrm{a}}$ \\
Vranov nad Topl’ou & 12.5 & 18.7 & 14.6 & 4.2 & 0.0 & 12.5 & 8.1 & 6.2 & 4.2 & 4.2 & 4.2 & 10.2 & $8.3^{\mathrm{d}}$ \\
\hline Average & 9.4 & 12.1 & 10.2 & 2.5 & 0.5 & 3.8 & 3.2 & 1.9 & 4.8 & 1.1 & 2.7 & 5.3 & 4.7 \\
\hline
\end{tabular}

gram $-F$. graminearum; poae $-F$. poae; sporo $-F$. sporotrichioides; culm $-F$. culmorum; tric $-F$. tricinctum; semit $-F$. semitectum; aven -F. avenaceum; samb - F. sambucinum; oxys - F. oxysporum; equi - F. equiseti; com - F. compactum; Mn - M. nivale; * differences between values designated by the same letter are not significant (ANOVA, Duncan test, $\mathrm{p}=0.05$ ) 
the third decade of June was the warmest, with the average temperatures from $20^{\circ} \mathrm{C}$ to $24^{\circ} \mathrm{C}$. These temperatures together with sufficient rainfall create optimal conditions for development and spreading of Fusarium species. Considering the sites with higher altitude, there was in these sites probably the shift in flowering, which took place at these higher temperatures. In earlier publications was the occurrence of individual species presented according to temperature and rainfall conditions (Šrobárová 1995; Mesterházy 1997; Bottalico \& Perrone 2002). Climatic changes recorded in recent years have changed the geographical and altitudinal distribution of individual Fusarium species (Hudec 2006; Stepień et al. 2008). In the years 2007 and 2008, F. poae became the dominant species with the average frequency of $65.1 \%$, and $64.9 \%$, respectively (Fig. 1). The composition of species was not changed, only the dominance of species was changed. In 2007, the highest relative density was found in $F$. poae in the locality Malý Šariš (43.7\%, Table 2). This species maintained its dominant position also in 2008, when the relative density reached $42.4 \%$ in the Abrahám location and the average relative density was $12.1 \%$. The prevalence of this species in Slovakia was also recorded in the works of Roháčik \& Hudec (2005), and Mašková et al. (2009). Regarding localities, the highest average frequency of Fusarium species in 2007 was recorded in Turčiansky Ďur (Fig. 2), 12 Fusarium species were identified. The frequency of occurrence of individual Fusarium species in this area was from $20 \%$ to $80 \%$, the highest frequency was in $F$. poae $(80 \%)$. In the species F. graminearum, F. oxysporum, F. sporotrichioides and $F$. semitectum the frequency of occurrence was $60 \%$ and $40 \%$ in F. culmorum, F. equiseti, $F$. compactum and F. tricinctum. The highest average relative density was found in $F$. poae $(15.8 \%$, Table 2$)$, and in the area of Malý Šariš it also reached the highest relative density (43.7\%). In 2008, the highest average occurrence frequency of Fusarium spp. was recorded in the locality Turčiansky Ďur (53.9\%, Fig. 1), where 11 Fusarium species were identified, and $F$. poae had the frequency of $100 \%$. F. graminearum, F. culmorum, F. semitectum and F. sambucinum had identically $80 \%$ frequency of occurrence. The highest relative density was recorded in F. poae in Abrahám locality (42.4\%, Table 3). In the locality Turčiansky Duur F. graminearum had the relative density of $29.2 \%$ and F. culmorum $15.4 \%$, which is for this type in our observations

$\mathrm{T}$ a b 1 e 4

The average of rainfall and air temperature in June in 2006-2008 from ten localities of Slovakia

\begin{tabular}{|l|l|c|c|c|c|c|c|}
\hline \multirow{2}{*}{ Locality } & Meteorological & \multicolumn{2}{|c|}{2006} & \multicolumn{2}{|c|}{2007} & \multicolumn{2}{|c|}{2008} \\
\cline { 2 - 8 } & observatory & {$[\mathrm{mm}]$} & {$\left[{ }^{\circ} \mathrm{C}\right]$} & {$[\mathrm{mm}]$} & {$\left[{ }^{\circ} \mathrm{C}\right]$} & {$[\mathrm{mm}]$} & {$\left[{ }^{\circ} \mathrm{C}\right]$} \\
\hline Abrahám & Žihárec & 123 & 20.1 & 81 & 21.2 & 101 & 20.9 \\
Velký Meder & Podhájska & 74 & 19.8 & 82 & 21.3 & 94 & 21.0 \\
Želiezovce & Mochovce & 107 & 18.9 & 75 & 20.5 & 97 & 20.0 \\
Sládkovičovo & Žihárec & 123 & 20.1 & 81 & 21.2 & 101 & 20.9 \\
Vel'ké Ripňany & Topol'čany & 65 & 19.8 & 59 & 20.6 & 55 & 21.0 \\
Turčiansky Ďur & Turčianske Teplice & 67 & 16.5 & 127 & 17.5 & 144 & 17.8 \\
Malý Šariš & Jakubovany & 111 & 17.2 & 69 & 19.0 & 55 & 18.2 \\
Spišské Vlachy & Spišské Vlachy & 248 & 16.1 & 62 & 18.2 & 44 & 17.8 \\
Spišská Belá & Spišské Vlachy & 248 & 16.1 & 62 & 18.2 & 44 & 17.8 \\
Vranov nad Topl’ou & Kamenica nad Cirochou & 121 & 17.6 & 75 & 19.8 & 126 & 18.5 \\
\hline Average & 128.7 & 18.2 & 77.3 & 18.3 & 86.1 & 19.4 \\
\hline
\end{tabular}

$\mathrm{mm}$ - sum of rainfall

${ }^{\circ} \mathrm{C}$ - average daily temperature

Resource: Slovak hydrometeorological institute Bratislava

Agrometeorological and fenological informations 2006, 2007, 2008 
the highest value, although the overall decline of occurrence was recorded (Fig. 1). A similar trend was observed in Poland (Stepień et al. 2008), Czech Republic (Nedělník et al. 2007), Austria (Adler et al. 2002), the Netherlands (Waalvijk et al. 2003). One explanation could be mono-cultivation of wheat, minimizing tillage (Lukanowski \& Sadowski 2002) and growing of maize as a forecrop, crop residues of maize are the main source of $F$. graminearum.

\section{CONCLUSIONS}

Slovakia is a country with diverse geographical division and fluctuating weather conditions. The frequency of occurrence and spectrum of Fusarium species are not stable. In 2007 and 2008 a change was observed in species prevalence, when the prevalence of Fusarium poae was ascertained. Higher number of Fusarium spp. (12) was identified in locality Turčiansky Dur. Dominant species, as so as F. poae, F. graminearum and F. sporotrichioides maintained a higher frequency and relative density in all localities and years. Less important species as F. sambucinum, F. equiseti. F. tricinctum and Microdochium nivale achieved low relative density in population structure also in areas with favourable climatic conditions.

Acknowledgement: This work was supported by OP Research and Development: Development of new types of genetically modified plants with farm traits (ITMS 26220220027) from European Regional Development Fund.

\section{REFERENCES}

ADLER, A. et al. 2002. Fusaria in Austrian cereals - change in species and toxins spectrum. In Journal of Applied Genetics, vol. 43A, 2002, pp. 11-16.

BOttalico, A. - PERRONE, G. 2002. Toxigenic Fusarium species and mycotoxins associated with heat blight in small-grain cereal in Europe. In European Journal of Plant Pathology, vol. 108, 2002, no. 2, pp. 611-624.

DOOHAN, F.M. et al. 2003. Influence of climatic factors on Fusarium species pathogenic to cereals. In European Journal of Plant Pathology, vol. 109, 2003, no. 7, pp. 755-768. DOI 10.1023/A:102609066994.

GERLACH, W. - NIRENBERG, H.I. 1982. The Genus Fusari$u m$ - a Pictorial Atlas. Berlin: Paul Parey, 1982. 406 pp.
GOLIŃSKI, P. et al. 1997. Fusarium species and Fusarium toxins in wheat in Poland - a comparison with neighbour countries. Sydowia (Special Issue March 1997), vol. 48, 1997, pp. 12-22.

GONZÁLES, H.H.L. et al. 1996. Deoxynivalenol and contamination mycoflora in freshly harvested Argeninen wheat in 1993. In Mycopathologia, vol. 135, 1996, no. 2, pp. 129134.

HUDEC, K. 2006. Vplyv lokality a ročníka na výskyt húb z rodu Fusarium pri fuzarióze klasu a bázy stebla pšenice [Influence of locality and year on Fusarium species occurrence in Fusarium head blight and stalk rot of winter wheat]. In Agriculture (Pol'nohospodárstvo), vol. 52, 2006, no. 2, pp. 69-76.

HÝSEK, J. et al. 1999. Fusarioses of barley with Emphasis on the Content of Trichothecenes. In Plant Protection Science, vol. 36, 1999, no. 5, pp. 96-102.

LESLIE, J.F. - SUMMERELL, B.A. 2006. The Fusarium Laboratory Manual. Australia: Blackwell Publishing, 2006, 338 p. ISBN 978-0-8-8138-1919-8.

LÖIVEKE, H. et al. 2003. Fusarium fungi as potential toxicants on cereals and grain feed grown in Estonia during 1973-2001. In Agronomy Research, vol. 1, 2003, no. 2, pp. $185-196$.

LUKANOWSKI, A. - SADOWSKI, C. 2002. Occurrence of Fusarium on grain and heads of winter wheat cultivated in organic, integrated, conventional systems and monoculture. In Journal of Applied Genetics, vol. 43A, 2002, pp. 69-74.

MAČKINAITË, R. et al. 2006. Contamination of cereal grain by Fusarium micromycetes and their mycotoxins under Lithuanian climatic conditions. In Ekologija, 2006, no. 3, pp. 71-79.

MAŠKOVÁ, Z. et al. 2009. Spektrum druhov rodu Fusarium izolovaných zo pšenice slovenského pôvodu a toxinogenita vybraných kmeňov. In Mykologické listy, 2009, suppl., pp.82-83. ISBN 978-80-254-6038-2.

MESTERHÁZY, Á. 1997. Methodology of resistance testing and breeeding against Fusarium head blight in wheat and results of the selection. In Cereal Research Communications, vol. 25, 1997, pp. 631-637.

NEDĚLNÍK, J. et al. 2007. Fusarium spp. in Wheat Grain in the Czech Republic Analysed by PCR Method. In Plant Protection Sciences, vol. 43, 2007, no. 4, pp. 135-137.

OSTRÝ V. et al. 2004. Advances on the occurence of toxigenic fungi and mycotoxins in the Czech Republic. In „, $A n$ Overview on Toxigenic Fungi and Mycotoxins in Europe“. Dordrecht-Boston-London: Kluwer, 2004. ISBN 1-40202646-3, pp. 67-81.

ROHÁČIK,T. - HUDEC, K. 2005. Influence of agro-environmental factors on Fusarium infestation and population structure in wheat kernels. In Annals of Agricultural and Environmental Medicine, vol. 12, 2005, pp. 39-45.

STENGLEIN, S.A. 2009. Fusarium poae: A pathogen that needs more attention. In Journal of Plant Pathology, vol. 91, 2009, no. 1, pp. 25-36.

STEPIEŃ. L. et al. 2008. Wheat-infecting Fusarium species in Poland - their chemotypes and frequencies revealed by PCR assay. In Journal of Applied Genetics, vol. 49, 2008 , no. 4, pp. 433-441.

ŠROBÁROVÁ, A. 1995. The occurence and biology of some 
Fusarium spp., on wheat in Slovakia. Ivanka pri Dunaji: Inst. of Exp. Phytopathol. and Entomol., Slovak Academy of Science: STU Bratislava, 1995. 119 pp.

TANČINOVÁ, D. et al. 2009. Endogénna kontaminácia v zrnách potravinárskej pšenice dopestovanej na Slovensku v sezóne 2007 [Endogenous contamination of wheat grains harvested in Slovakia during the season 2007]. In Acta fytotechnica at zootechnica, special issue, 2009, pp. 639-651.

TOMCZAK, M. et al. 2002. Deoxynivalenol, nivalenol and moniliformin occurrence in wheat samples with scab symptoms in Poland (1998-2000). In European Journal of Plant Pathology, vol. 108, 2002, pp. 625-630.

VOGELGSANG, S. et al. 2008. Toxigenicity and pathogenicity of Fusarium poae and Fusarium avenaceum on head.
In European Journal of Plant Pathology, vol. 122, 2008, pp. 265-276.

WAALWIJK, C. et al. 2003. Major changes in Fusarium spp. in wheat in the Netherlands. In European Journal of Plant Pathology, vol. 109, 2003, no. 7, pp. 743-754.

ZEMÁNKOVÁ, M. - LEBEDA, A. 2001. Fusarium species, their taxonomy, variability and significance in plant pathology. In Plant Protection Sciences, vol. 37, 2001, no. 1, pp. $25-42$.

XU, X. 2003. Effect of environmental conditions on the development of Fusarium ear blight. In European Journal of Plant Pathology, vol. 109, 2003, no. 7, pp. 683-689.

Received: March, 29 $9^{\text {th }}, 2011$ 